\title{
Research on the Labor Productivity of the Countries in "the Belt and Road"
}

\author{
Lirui Dong ${ }^{a}$, Meixia Shi ${ }^{b}$ \\ Beijing Jiaotong University, Beijing, China \\ a17120738@bjtu.edu.cn, ${ }^{\mathrm{b}} \mathrm{mxshi@bjtu.edu.cn}$
}

Keywords: "the Belt and Road", Labor productivity, Comparison, Influencing factors.

\begin{abstract}
Since "the Belt and Road" strategy was put forward, China has been in close contact with countries along the lines, aiming to achieve mutual benefit and win-win results. Labor productivity is an important factor in the analysis of industrial cooperation among countries, and its improvement can also stimulate the rapid growth of the economy. Therefore, it is of great significance to study the labor productivity of these countries in exploring the future of economic cooperation between China and these countries. In this paper, labor productivity of the countries in "the Belt and Road" are conducted a specific analysis and comparison by collecting relevant data. Finally, it is concluded that the level of labor productivity of these countries is closely related to the overall economic development status. The growth rate is basically in line with the trend of economic development. This conclusion has a positive theoretical and practical significance for the better implementation of "the Belt and Road" strategy.
\end{abstract}

\section{Introduction}

Labor productivity refers to the ratio of labor output to labor input, which reflects the efficiency of labor production in a certain period. The logarithm differential of the formula "labor productivity = actual GDP / labor input" results in "economic growth is about equal to the sum of labor productivity growth and employment growth", which shows that there is a positive correlation between economic growth and labor productivity growth [1]. In addition, from a microscopic point of view, the increase in labor productivity is conducive to reducing the production costs of enterprises, improving organizational management and promoting the rational allocation of resources. From a macro perspective, the improvement of this factor is conducive to promoting employment, promoting the development of the country's economy, improving people's living standards and enhancing their international competitiveness. Therefore, labor productivity is often used as an important measure of a country's overall national strength.

At the same time, labor productivity is a complex factor, and there are many factors that affect its improvement. Essentially, labor productivity is determined by the level of productivity development in a country or region. The higher the level of productivity development, the higher the labor productivity. On the contrary, the lower the labor productivity. Specifically, labor productivity is affected by many factors such as the level of scientific and technological development, the accumulation of human capital, industrial structure, production management and macroeconomic policies. Among them, in terms of the level of technological development, the higher the level of technological development, the more favorable it is to increase labor productivity. Especially when technology is the primary productive force, the importance of technological progress is even more pronounced. In the accumulation of human capital, talents, as a part of the cost of production, can have an important positive impact on improving the labor productivity of enterprises if they are lean in their management [2]. In the industrial structure, the increase in the proportion of the second and third industries will promote the improvement of labor productivity [3]. At the level of production management, the use of different management methods has a direct impact on production work schedules, cost expenditures and other issues that are closely related to labor productivity. Therefore, effective production management methods are conducive to the improvement of labor productivity. 
In terms of macroeconomic policies, on the one hand, macroeconomic policies can guide the development of social economy and the improvement of economic structure through various means such as fiscal policies and monetary policies so as to increase labor productivity. On the other hand, various economic activities are legally compliant, so any changes in labor productivity in any way must be affected by relevant macroeconomic policies.

In addition, "the Belt and Road” strategy has established a new platform for economic cooperation among countries and is an important manifestation of China's deepening of its opening up to the outside world. With the advancement of "the Belt and Road" strategy, China's contacts with countries along "the Belt and Road" have become increasingly close and economic cooperation has gradually increased. Moreover, due to the differences in the factor endowments of countries, which constitute the comparative advantages of countries participating in the international division of labor and trade [4], it is necessary to analyze the characteristics of the economic development of these countries. Labor productivity, as an important measure of economic development, its status and changes reflect the situation of productivity in the country or the region. Therefore, it is of great significance to analyze and study of labor productivity of the countries along the lines in order to carry out economic cooperation between China and these countries more effectively and implement "the Belt and Road" strategy better.

\section{Comparison and analysis of labor productivity among different countries in different regions}

At present, there are 66 countries (including China) along "the Belt and Road" in East Asia, Central Asia, South Asia, West Asia, ASEAN and Central and Eastern Europe. Affected by the physical and geographical conditions, the economic development of different regions presents different characteristics. However, different countries in the same region have certain similarities and particularities. Therefore, when analyzing the labor productivity of countries, comparing "the Belt and Road" countries in the same region can help to analyze the specificities of their labor productivity and the causes of their changes. At the same time, it is beneficial to grasp the overall development characteristics of these regions by comparing different regions. In addition, in the comparison and analysis of the labor productivity situation, the relevant data for each country in 2012 and 2017 were selected because "the Belt and Road" strategy was proposed in 2013. It is more conducive to analyzing the impact of the implementation of "the Belt and Road" strategy on labor productivity in China and related countries by selecting the data before and after the proposed strategy. And it also helps China to further study more appropriate cooperation methods with these countries.

\subsection{Comparison of labor productivity in East Asian countries, Central Asian countries and South Asian countries}

East Asian countries include China and Mongolia in "the Belt and Road”. Numerically, data for 2012 and 2017 shows that China's labor productivity is slightly higher than that of Mongolia. In terms of growth rate, although labor productivity in both countries has increased, China's growth rate is faster. In comparison, China and Mongolia have their own advantages in economic development and the reasons for promoting labor productivity are also different. At present, China is actively committing itself to the transformation of the economic structure, pursuing the new normality of the economy, vigorously developing high technology and training high-quality talents. These factors have greatly promoted the progress of China's labor productivity. Mongolia is rich in mineral resources. For a long time, the exploitation and export of resources has always been an important driving force for the country's economic development and the degree of industrial diversification is relatively low. In addition, the economic development model that uses natural resource development as a pillar industry is vulnerable to the cyclical impact of factors such as market demand for products and international market prices [5]. In particular, in recent years, Mongolia has been affected by the cyclical economic ups and downs and its economic growth rate has been slow. This has to a certain extent limited the growth rate of labor productivity in the country. 
Central Asian countries include Kazakhstan, Uzbekistan, Turkmenistan, Tajikistan and Kyrgyzstan in "the Belt and Road”. Among them, numerically, Kazakhstan and Turkmenistan have higher labor productivity while other three countries have lower labor productivity. And the labor productivity in the region varies greatly. The data for 2017 shows that among the five countries, Kazakhstan has the highest productivity and Tajikistan is the lowest. At the same time, the lowest is only $13 \%$ of the highest countries. This is closely related to the respective level of productivity of these countries. However, in the index of growth rate, Kazakhstan, which has the highest value of labor productivity, is the country with the slowest growth rate. Turkmenistan not only has higher labor productivity, but also has a faster growth rate. Uzbekistan and Kyrgyzstan have lower values, but the growth rates are higher. Tajikistan's labor productivity value and growth rate is small.

Table 1 Labor productivity in East, Central and South Asian countries.

\begin{tabular}{|c|c|c|c|c|}
\hline Area & Country & $\begin{array}{c}\text { Labor } \\
\text { productivity in } \\
2012 \\
\end{array}$ & $\begin{array}{c}\text { Labor } \\
\text { productivity in } \\
2017 \\
\end{array}$ & Growth rate \\
\hline \multirow{2}{*}{ East Asia } & China & 9445 & 13083 & $38.52 \%$ \\
\hline & Mongolia & 8131 & 10192 & $25.35 \%$ \\
\hline \multirow{5}{*}{ Central Asia } & Kazakhstan & 19645 & 20603 & $4.88 \%$ \\
\hline & Uzbekistan & 3677 & 5007 & $36.17 \%$ \\
\hline & Turkmenistan & 12421 & 18704 & $50.58 \%$ \\
\hline & Tajikistan & 2388 & 2715 & $13.69 \%$ \\
\hline & Kyrgyzstan & 2219 & 2769 & $24.79 \%$ \\
\hline \multirow{8}{*}{ South Asia } & India & 4054 & 5043 & $24.40 \%$ \\
\hline & Pakistan & 3236 & 3468 & $7.17 \%$ \\
\hline & Bangladesh & 2229 & 2816 & $26.33 \%$ \\
\hline & Afghanistan & 2455 & 2185 & $-11.00 \%$ \\
\hline & Sri Lanka & 8544 & 10463 & $22.46 \%$ \\
\hline & Maldives & 14024 & 17603 & $25.52 \%$ \\
\hline & Nepal & 1192 & 1300 & $9.06 \%$ \\
\hline & Bhutan & 5253 & 6368 & $21.23 \%$ \\
\hline
\end{tabular}

Note: Source: International Labor Organization. The labor productivity figures for 2012 and 2017 were calculated at a constant GDP of \$2010. The growth rate was calculated by the authors based on numerical calculations for 2012 and 2017.

South Asian countries include India, Pakistan, Bangladesh, Afghanistan, Sri Lanka, Maldives, Nepal and Bhutan in "the Belt and Road". Due to the constraints of natural geographical conditions and the stability of the political situation, the level of productivity in the region is low. Among them, except for Sri Lanka and the Maldives, labor productivity in other countries is lower. In addition, compared with 2012, the productivity level of Afghanistan in 2017 decreased, which is related to the current overall economic development. In terms of growth rate, with the exception of Pakistan, Afghanistan and Nepal, the growth rates of labor productivity in other countries are all above $20 \%$ and the growth rate is faster.

\subsection{Comparison of labor productivity in West Asian countries}

West Asian countries include Iran, Iraq, Turkey, Syria, Jordan, Lebanon, Israel, Palestine, Saudi Arabia, Yemen, Oman, the United Arab Emirates, Qatar, Kuwait, Bahrain, Cyprus, Egypt, Georgia, Azerbaijan and Armenia in "the Belt and Road". On the whole, the labor productivity of the 20 countries in West Asia is relatively high, with only Syria, Yemen, Egypt and Georgia under 10,000 in 2017. The factor is between 10,000 and 30,000 in Iran, Iraq, Jordan, Lebanon, Palestine, Azerbaijan and Armenia in 2017. It is higher than 30,000 in Turkey, Israel, Saudi Arabia, Oman, the United Arab Emirates, Qatar, Kuwait, Bahrain and Cyprus. The reason for the high overall labor productivity is that the oil resources in the region are abundant. The oil imports in most countries and regions in the world depend on West Asia. This makes West Asia's economy developed and its labor productivity relatively high. However, the labor productivity growth rates in 12 countries are negative. Though the labor productivity growth rates in the other countries are positive, the numbers are small. It means 
that the labor productivity growth is slow. This is because the situation in the region is relatively unstable, which has a certain degree of impact on its economic development and the improvement of labor productivity.

Table 2 Labour productivity in West Asian countries.

\begin{tabular}{|c|c|c|c|c|}
\hline Area & Country & $\begin{array}{l}\text { Labor productivity in } \\
2012\end{array}$ & $\begin{array}{l}\text { Labor productivity in } \\
2017\end{array}$ & Growth rate \\
\hline \multirow{20}{*}{ West Asia } & Iran & 20802 & 23640 & $13.64 \%$ \\
\hline & Iraq & 20796 & 19587 & $-5.81 \%$ \\
\hline & Turkey & 36570 & 42564 & $16.39 \%$ \\
\hline & Syria & 6200 & 3246 & $-47.65 \%$ \\
\hline & Jordan & 15545 & 15436 & $-0.70 \%$ \\
\hline & Lebanon & 24381 & 21387 & $-12.28 \%$ \\
\hline & Israel & 76169 & 84929 & $11.50 \%$ \\
\hline & Palestine & 12719 & 11706 & $-7.96 \%$ \\
\hline & Saudi Arabia & 57868 & 52734 & $-8.87 \%$ \\
\hline & Yemen & 5868 & 2812 & $-52.08 \%$ \\
\hline & Oman & 44819 & 34401 & $-23.24 \%$ \\
\hline & $\begin{array}{c}\text { the United Arab } \\
\text { Emirates }\end{array}$ & 53195 & 60699 & $14.11 \%$ \\
\hline & Qatar & 94957 & 87711 & $-7.63 \%$ \\
\hline & Kuwait & 74671 & 64345 & $-13.83 \%$ \\
\hline & Bahrain & 37207 & 43313 & $16.41 \%$ \\
\hline & Cyprus & 47784 & 43711 & $-8.52 \%$ \\
\hline & Egypt & 8943 & 9725 & $8.74 \%$ \\
\hline & Georgia & 6915 & 7890 & $14.10 \%$ \\
\hline & Azerbaijan & 12375 & 11981 & $-3.18 \%$ \\
\hline & Armenia & 8969 & 10042 & $11.96 \%$ \\
\hline
\end{tabular}

Note: Source: International Labor Organization. The labor productivity figures for 2012 and 2017 were calculated at a constant GDP of \$ 2010. The growth rate was calculated by the authors based on numerical calculations for 2012 and 2017.

\subsection{Comparison of labor productivity in ASEAN countries}

Table 3 Labor productivity in ASEAN countries.

\begin{tabular}{|c|c|c|c|c|}
\hline Area & Country & $\begin{array}{c}\text { Labor } \\
\text { productivity in } \\
2012 \\
\end{array}$ & $\begin{array}{c}\text { Labor } \\
\text { productivity in } \\
2017 \\
\end{array}$ & Growth rate \\
\hline \multirow{10}{*}{ ASEAN } & Singapore & 90388 & 94853 & $4.94 \%$ \\
\hline & Malaysia & 21877 & 24408 & $11.57 \%$ \\
\hline & Indonesia & 4054 & 5043 & $24.40 \%$ \\
\hline & Myanmar & 2346 & 3123 & $33.12 \%$ \\
\hline & Thailand & 9252 & 10915 & $17.97 \%$ \\
\hline & Laos & 2578 & 3172 & $23.04 \%$ \\
\hline & Cambodia & 1526 & 1967 & $28.90 \%$ \\
\hline & Vietnam & 2444 & 2963 & $21.24 \%$ \\
\hline & Brunei & 75016 & 74435 & $-0.77 \%$ \\
\hline & Philippines & 5646 & 7235 & $28.14 \%$ \\
\hline
\end{tabular}

Note: Source: International Labor Organization. The labor productivity figures for 2012 and 2017 were calculated at a constant GDP of \$ 2010. The growth rate was calculated by the authors based on numerical calculations for 2012 and 2017.

ASEAN countries include Singapore, Malaysia, Indonesia, Myanmar, Thailand, Laos, Cambodia, Vietnam, Brunei, and the Philippines in "the Belt and Road". From a numerical point of view, with the exception of Singapore and Brunei, labor productivity in other countries is lower. At the same time, there is a large gap between the highest country, Singapore (94853) and the lowest country, 
Cambodia (1967). However, from the perspective of growth rate, the three countries with high labor productivity in the numerical level are the three with low growth rates, especially Brunei where the growth rate is negative. The reason for the low labor productivity growth rate in Brunei is that the economic structure of Brunei is relatively simple. With the development of economy and society, it is difficult to maintain the sustained prosperity of the economy by relying solely on the exploitation and export of non-renewable energy such as oil and natural gas.

\subsection{Comparison of labor productivity in Central and Eastern European countries}

Table 4. Labor productivity in Central and Eastern European countries.

\begin{tabular}{|c|c|c|c|c|}
\hline Area & Country & $\begin{array}{l}\text { Labor productivity } \\
\text { in } 2012\end{array}$ & $\begin{array}{l}\text { Labor productivity } \\
\text { in } 2017\end{array}$ & Growth rate \\
\hline \multirow{21}{*}{$\begin{array}{c}\text { Central and } \\
\text { Eastern Europe }\end{array}$} & Russia & 22628 & 25402 & $12.26 \%$ \\
\hline & Ukraine & 7301 & 6832 & $-6.42 \%$ \\
\hline & Belarus & 12097 & 12494 & $3.28 \%$ \\
\hline & Moldova & 4683 & 4840 & $3.35 \%$ \\
\hline & Poland & 30997 & 33878 & $9.29 \%$ \\
\hline & Lithuania & 31260 & 35515 & $13.61 \%$ \\
\hline & Estonia & 35445 & 38046 & $7.34 \%$ \\
\hline & Latvia & 29242 & 33062 & $13.06 \%$ \\
\hline & Czech Republic & 42431 & 46240 & $8.98 \%$ \\
\hline & Slovakia & 40043 & 42428 & $5.96 \%$ \\
\hline & Hungary & 33708 & 34016 & $0.91 \%$ \\
\hline & Slovenia & 50663 & 56549 & $11.62 \%$ \\
\hline & Croatia & 37011 & 37580 & $1.54 \%$ \\
\hline & $\begin{array}{c}\text { Bosnia and } \\
\text { Herzegovina }\end{array}$ & 16194 & 18554 & $14.57 \%$ \\
\hline & Montenegro & 20640 & 22895 & $10.93 \%$ \\
\hline & Serbia & 13664 & 12621 & $-7.63 \%$ \\
\hline & Romania & 19745 & 24732 & $25.26 \%$ \\
\hline & Bulgaria & 17525 & 19297 & $10.11 \%$ \\
\hline & Macedonia & 14687 & 15209 & $3.55 \%$ \\
\hline & Albania & 10742 & 11925 & $11.01 \%$ \\
\hline & Greece & 64276 & 62238 & $-3.17 \%$ \\
\hline
\end{tabular}

Note: Source: International Labor Organization. The labor productivity figures for 2012 and 2017 were calculated at a constant GDP of \$ 2010. The growth rate was calculated by the authors based on numerical calculations for 2012 and 2017.

Central and Eastern European countries include Russia, Ukraine, Belarus, Moldova, Poland, Lithuania, Estonia, Latvia, Czech Republic, Slovakia, Hungary, Slovenia, Croatia, Bosnia and Herzegovina, Montenegro, Serbia, Romania, Bulgaria, Macedonia, Albania and Greece in "the Belt and Road”. Labor productivity is higher in the countries except Ukraine and Moldova. Ukraine's economy is affected by the overall situation, which affects its labor productivity to a certain extent. In Moldova, agriculture plays a dominant role in the economic structure and the food industry is relatively developed. But at the same time, the country is short of energy resources such as oil and gas, the infrastructure is not perfect and the economic situation needs to be improved. The level of labor productivity in the country is affected by these factors. Growth rates in Ukraine, Serbia and Greece are negative. 


\section{Comparison of labor productivity among different regions}

Table 5 Average labor productivity in 2012 and 2017 and growth rate in China and different regions.

\begin{tabular}{cccc}
\hline Area & $\begin{array}{c}\text { Average labor } \\
\text { productivity in 2012 }\end{array}$ & $\begin{array}{c}\text { Average labor } \\
\text { productivity in 2017 }\end{array}$ & Growth rate \\
\hline East Asia & 8788 & 11637.5 & $32.42 \%$ \\
\hline ASEAN & 21512.7 & 22811.4 & $6.04 \%$ \\
\hline West Asia & 34162.25 & 33519.3 & $-1.88 \%$ \\
\hline South Asia & 5123.375 & 6155.75 & $20.15 \%$ \\
\hline Central Asia & 8070 & 9959.6 & $23.42 \%$ \\
\hline $\begin{array}{c}\text { Central and } \\
\text { Eastern Europe }\end{array}$ & 26427.71 & 28302.52 & $7.09 \%$ \\
\hline China & 9445 & 13083 & $38.52 \%$ \\
\hline
\end{tabular}

Note: Source: International Labor Organization. The labor productivity figures for 2012 and 2017 were calculated at a constant GDP of \$ 2010. The average labor productivity in 2012 and 2017 and the growth rate in China and different regions were calculated by the authors based on numerical calculations for 2012 and 2017.

As can be seen from the table 5, among the countries along "the Belt and Road", 20 countries in West Asia, 21 countries in Central and Eastern Europe and 10 ASEAN countries have higher labor productivity, which are all above 20,000. However, the growth rates of labor productivity in these countries for the past five years are relatively low and the growth rate is negative in 20 West Asian countries. For West Asia, oil resources are abundant. Many countries use oil as the mainstay of national development and the labor productivity remains at a relatively high level. However, with the development of science and technology and the discovery of many emerging energy sources, it is difficult to further increase labor productivity only relying on energy extraction and export without technical progress. On the whole, the economic development is good and the labor productivity is high in Central and Eastern European countries. However, in the region, the growth rate of labor productivity is relatively low. The countries in ASEAN are mainly developing countries. Currently, it is in a period of undertaking foreign industries. The overall economic development is relatively good and the labor productivity is generally higher. However, due to the fact that the main industries are labor-intensive industries, the growth rate in the region is low. The labor productivity in China is at an intermediate level and there is still much room for improvement. At the same time, the growth rate in China is the highest. This is mainly related to China's commitment to technology research and innovation in recent years. The situation is similar in East Asia, Central Asia and South Asia where the labor productivity is low, but the growth rate is high.

\section{Conclusion}

Given the fact that the labor force grows slowly in the world, the improvement of labor productivity is of great significance. Through comparison and analysis of labor productivity and growth rate in countries along "the Belt and Road", it can be found that labor productivity varies not only among countries in the same region, but also among different regions. The causes of the differences are also different. In addition, we can also find that the level of labor productivity is closely related to the countries' overall economic development. For example, among the 10 ASEAN countries, the economic development of Singapore and Brunei has been improving for a long time. Therefore, their labor productivity is at a relatively high level. The economic development of Malaysia and Thailand is overall in a medium-ranking position, so their labor productivity is in the middle. Although the economies in Indonesia, Myanmar, Laos, Cambodia, Vietnam and the Philippines have developed rapidly in recent years, the overall level is low. So the labor productivity in these countries is relatively low. At the same time, the growth rates of labor productivity in various countries are basically in line with the changes in their economic development. For example, in recent years, with the development of new energy sources and increased environmental protection efforts, the economies of some countries that use energy extraction and export as a pillar industry have been 
affected to a certain extent and the development speed in these countries is limited. This has led to a decrease in labor productivity. These countries include Saudi Arabia, Qatar and so on.

Therefore, in the process of actively implementing "the Belt and Road", we must earnestly understand the situation and trends of labor productivity in each country, analyze the characteristics of the countries' economic development and select appropriate cooperation methods in order to achieve mutual benefits and win-win results. For example, if a country's labor productivity is low due to the singleness and backwardness of its traditional industrial structure, China can strengthen the cooperation with the country in terms of technology and services, which not only meets the country's demand for the development of non-energy industries, but also is conducive to promoting China's economic growth and achieving a win-win situation. There are many ways to achieve interconnection and cooperation, such as methods of trade, methods of investment, methods of labor services, methods of technical exchanges, methods of building infrastructure, methods of cultural exchanges and so on [6]. These methods can be used alone or combined. In short, labor productivity is an important factor that affects China's cooperation with other countries. The analysis of labor productivity in countries along "the Belt and Road" will help to advance "the Belt and Road" more deeply and promote the common prosperity of China and other countries.

\section{Acknowledgements}

This research is supported by the Project of Humanities and Social Sciences Research and Planning Fund of Ministry of Education (Grant No. 18YJA630092) and by the "Infrastructure Networks along 'the Belt and Road': the Status Quo, Needs and Potential” (Grant No. 2017JBZ005).

\section{References}

[1] B. Chen and G.W. Dai, Comparison of labor productivity in the Yangtze River Delta region, China Finance, no.9, pp.83-85, 2009.

[2] S.R. Wang, Analysis of the positive influence of lean management of human resources on labor productivity of enterprises, Human Resource Management, no.3, pp.78-80, 2016.

[3] J.D. Huang, Influence factor of productivity - theoretical study and empirical test based on panel data(1988-2008), M.S.thesis, Chongqing Ligong University, Chongqing, China, 2011.

[4] Z.Q. Liu and Y. Zhang, “The Belt and Road” and China's economic reopening, Hubei Social Sciences, no.10, pp.78-84, 2017.

[5] Tsambaa Gantulga, Study on the labor and economy growth in Mongolia, M.S.thesis, Jilin Unversity, Jilin, China, 2015.

[6] T.H. Sun, Study on the economic interaction strategy of "the Belt and Road" initiative, Dongbei Caijing University, Liaoning, China, 2016. 